\title{
III. Toxikologie.
}

\section{Ueber Wachsstockfarben.}

Von Julius Müller, Apotheker in Breslau.

Da der Apotheker, namentlich der in kleinen Städten, gewiss die Pflicht hat, in sanitätspolizeilicher Hinsicht gleichsam Aufsichtsbehörde zu sein, so will ich auf eine Gewissenlosigkeit aufmerksam machen, die meiner Ansicht nach nicht streng genug gerügt werden kann.

Ich erhielt zur Untersuchung verschieden gefärbte Wachsstocksorten "weiss, schwarı, gelb, orange, blau, zweierlei roth und grün." -

Das weisse Wachs gab auf Platinblech erhitzt einen nur höchst unbedeutenden Rückstand und löste sich in heissem Aether völlig auf; es war also reines gebleichtes Wachs, ohne jeden Farbenzusatz.

Das gelbe Wachs zeigte auf Platinblech erhitzt einen gelben Rückstand, der sich in Kalilauge leicht zu einer gelben, durch Schwefelwasserstoffwasser sofort schwarz fällenden Flüssigkeit löste; es war also als Färbemittel $\mathrm{Chromgelb}$ - chromsaures Bleioxyd - verwandt worden, eine hier entschieden nicht giftige Farbe, da ich das Blei im verkohlten Dochte als chromsaures Bleioxyd wiederum völlig nachweisen konnte.

Das orange Wachs zeigte ganz dieselbe Reaction wie das gelbe; es war also mit sogenanntem Chromzinnober, basisch chromsaurem Bleioxyd - gefärbt. Aus dem angeführten Grunde ist selbstverständlich auch diese Farbe hier als völlig unschädlich zu bezeichncn. -

Das blaue Wachs hinterliess auf Platinblech erhitzt einen schönen blauen Rückstand, der mit Salzsäure über- 
gossen sich unter Schwefelwasserstoffentwickelung zu einer farblosen, mit Ammoniak einen weissen gallertartigen Niederschlag gebenden Flüssigkeit löste. Der Farbstoff war also blaues Ultramarin - völlig unschädlich. -

Das schwarze Wachs gab nach anhaltendem Erhitzen auf Platinblech einen weissen Rückstand, der in Salzsäure sich löste. Die Lösung erzengte in angesäuerter molybdänsaurer Ammoniaklösung die bekannte Phosphorsäure-Reaction; es war das schwarze Wachs also mit Ebur ustum gefärbt.

Das rothe Wachs und zwar das dunklere war mit Carmin gefärbt. Es gab auf Platinblech erhitzt fast gar keinen Rückstand. Mit heissem Aether ausgezogen, hinterliess das Wachs einen rothen Farbstoff, der sich in Salmiakgeist mit prachtvoll rother Farbe löste; Carmin ist selbstrerständlich völlig unschädlich.

Das hellere rothe Wachs war ebenfalls beim Erhitzen fast völlig flüchtig. Nach dem Lösen des Wachses in heissem Aether blieb ein rother Farbstoff, von dem ein Theilchen mit ammoniakalischer Silberlösung übergossen, schwarz wurde und von dem ein anderes Theilchen in Königswasser gelöst, die Lösung abgedampft und der Rückstand mit Wasser aufgenommen, die charakteristischen QuecksilberReactionen gab. Der Farbstoff war also Zinnober an sich nicht giftig, ist derselbe gerade hier gewiss als nicht unschädlich zu bezeichnen, da beim Erhitzen des Zinnobers unter Zutritt der Luft Quecksilber frei wird. Ein kleiner Wachsstock für $1 \mathrm{Sgr}$., der ungefähr $1 \frac{1}{2}$ Stunde brennt, enthielt $11 / \mathbf{2}^{\prime}$ rothen mit Zinnober gefärbten Zug; in demselben fand ich 0,12 Gr. Zinnober, dies entspricht etwas über 0,10 Gr. metallischem Queoksilber. Ganz unvergleichlich schädlicher und mit allen Mitteln zu verfolgen aber ist

das grüne Wachs, welches mit Schweinfurter Grün oder einer anderen arsenikalischen Kupferfarbe gefärbt ist. Leicht konnte ich mich in dem mir zur Untersuchung gegebenen Wachsstockzug von der Anwesenheit einer Arsenikfarbe überzeugen. Nur eine kleine Menge 
ron demselben in den Marsh'schen Apparat gebracht, gab die deutlichste Arsen-Reaction; ja ich brauchte blos den Wachsstock anzuzünden, eine Porzellanschaale über die Flamme zu halten, nach 3 Minuten langem Brennen die Schaale mit Salzsäure zu befeuchten und dann Schwefelwasserstoffwasser zuzufügen, so erhielt ich den deutlich gelben Niederschlag von Schwefelarsen. - Um mich zu überzeugen, wie bedeutend die zum Färben angewandte Menge des Schweinfurter Grüns oft ist, verschaffte ich mir unter Andern einen bunten kleinen Wachsstock für $1 \mathrm{Sgr}$., derselbe brennt $1 \frac{1}{2}$ Stunden lang und enthielt $11^{1} \mathbf{2}^{\prime}$ grünen Zug. Die vom Docht abgezogene Menge des grünen Wachses betrug 2,4 Gr. und in demselben waren $0,24 \mathrm{Gr}$. d. 's. $10 \%$ Schweinfurter $\mathrm{Grün}$; diese $0,24 \mathrm{Gr}$. entsprechen 0,13 arsenige $\mathrm{S} \ddot{u} u r e$, nach altem Gewicht also 21/6 Gr. Bedenkt man nun, dass einige Gran arsenige Säure genossen bisweilen tödtlich wirken und dass beim Verbrennen des grünen Wachsstockes alle arsenige Säure - so hier also $0,13 \mathrm{Gr}$. - in die Luft gelangt, so ist trotz der grossen Vertheilung beim Verbrennen in Zimmern doch wahrlich die Gefährlichkeit eine ganz erhebliche und das Verbot, Wachsstöcke mit Schweinfurter Grün färben zu dürfen, ein gewiss wünschenswerthes.

Breslau, den 21. Mai 1870. 